\title{
SYSTEMIC AND LOCAL DELIVERY OF ANTIBIOTICS IN MANAGING PERIODONTAL DISEASES: AN UPDATE
}

\author{
Abdul Khabeer ${ }^{1}$, Beenish Fatima Alam ${ }^{2}$, Sara Noreen ${ }^{3}$, Muhammad Ali Faridi ${ }^{1}$, Saqib Ali ${ }^{4}$ \\ ${ }^{1}$ Department of Restorative Dental Sciences, College of Dentistry, Imam Abdulrahman Bin Faisal University, \\ Dammam - Kingdom of Saudi Arabia \\ ${ }^{2}$ Department of Oral Biology, Bahria University Medical and Dental College, Karachi - Pakistan \\ ${ }^{3}$ Department of Medicine, Khyber Teaching Hospital, Peshawar - Pakistan \\ ${ }^{4}$ Department of Biomedical Dental Sciences, College of Dentistry, Imam Abdulrahman Bin Faisal University, \\ Dammam - Kingdom of Saudi Arabia
}

\begin{abstract}
Objective: The aim of this update was to evaluate the use of local and systemic antibiotics for the treatment of periodontal diseases. PubMed and google scholar databases were used to search through the past 30 years of literature using selected search criteria "Periodontal diseases*[TW] AND (gingivitis*[TW] OR periodontitis*[TW] OR antibiotics*[TW])" to identify articles/book chapters discussing polymerization shrinkage and possible solutions. In total, 46 articles/book chapters met the criteria for inclusion in the literature review.

Due to the accumulation of bacteria in the form of dental plaque, the tissues and bone surrounding the teeth can become infected leading to periodontal diseases such as gingivitis and periodontitis. The main purpose of periodontal therapy is to eliminate or control the undesired effects of these bacteria present in the oral cavity in the form of biofilms. The use of antibiotics in conjunction with mechanical instrumentation has been suggested for the successful treatment of periodontal diseases.

It can be concluded that the use of antibiotics is justified in cases with rapid signs and symptoms of destruction of periodontal tissues. Hence, antibiotics are suggested in cases of aggressive periodontitis, periodontal abscess, necrotizing ulcerative gingivitis, necrotizing ulcerative periodontitis and periodontitis that do not respond well to mechanical instrumentation alone. However, antibiotics may cause side effects and the bacteria may develop resistance, therefore dentists should keep in mind the adverse effects and benefits while prescribing antibiotics. Moreover, antibiotics should always be given as an adjunct to mechanical instrumentation and oral hygiene instructions to achieve successful outcome.
\end{abstract}

Keywords: Periodontal diseases, gingivitis, periodontitis, local antibiotics, systemic antibiotics.

This article may be cited as: Khabeer A, Alam, BF, Noreen S, Faridi MA, Ali S. Systemic and local delivery of antibiotics in managing periodontal diseases: An update. J Med Sci 2021 July;29(3):120-125

\section{INTRODUCTION}

In ideal conditions, every individual wants natural healthy teeth throughout their life for aesthetics, form and function. However, due to accumulation of bacteria in the form of dental plaque, the tissues and bone surrounding the teeth can become infected which can be termed as periodontal disease ${ }^{1}$. (Table 1) Periodontal diseases are inflammatory disorders of chronic nature and can include gingivitis and periodontitis. Gingivitis is defined as inflam-

\section{Correspondence}

Dr. Saqib Ali

Department of Biomedical Dental Sciences, College of Dentistry, Imam Abdulrahman Bin Faisal University, Dammam - Kingdom of Saudi Arabia

Email: drsaqiibali@gmail.com

Cell: +966 (0) 546992734

Date received: $07-11-2020$

Date revised: $\quad 06-08-2021$

Date accepted: $08-08-2021$ mation of gingiva only, while periodontitis is inflammation of tissues around teeth which can result in loss of surrounding ligaments and alveolar bone, eventually leading to loss of teeth from the sockets. ${ }^{2,3}$ The main difficulty in managing periodontal diseases arises from the bacteria which are not only present in the biofilm but also present throughout the oral cavity, thus making them almost impossible to eliminate. ${ }^{4}$ To prevent the loss of teeth, periodontal therapy is performed which aims to eliminate or reduce the amount of pathogens by mechanical debridement. ${ }^{5}$ However, due to surface anomalies on the teeth and adjacent epithelium, certain bacteria may still remain in periodontal pockets resulting in recolonization and making the mechanical debridement less effective. ${ }^{6}$ Moreover, certain individuals do not respond well to mechanical therapy, therefore, many dentists and microbiologists appreciate the use of antibiotics. ${ }^{6,7}$ Antibiotics help in reducing the amount of bacteria, thus helps in decreasing the inflammation of diseased tissues. ${ }^{8}$ Haffajee reported a 
clinical study in which he found increased clinical attachment gains and decrease in number of pathogens when treated with antibiotics as an adjunct to root surface instrumentation (RSI). ${ }^{9}$ Main reason for the use of antibiotics could have been the realization during 1970 s that certain types of bacteria were involved in periodontal diseases. ${ }^{10}$ Since then, the use of antibiotics became an interesting element of periodontal therapy.

\section{MATERIALS AND METHODS}

Electronic search of PubMed/Medline and google scholar databases was done. A total of 647 articles were evaluated and screen for parameters including periodontal diseases and the use of antibiotics in relation to periodontal diseases. The search was carried out using the following criteria "Periodontal disease*[TW] AND (Gingivitis*[TW] OR Periodontitis *[TW] OR antibiotics*[TW])". The studies that were duplicate, not in English language and not published in dental journals were excluded. Studies published between the years 1990 and 2018 that evaluated the periodontal diseases, there management and treatment strategies or reported strategies for treating periodontal diseases and use of antibiotics for inclusion. In the end, 46 articles/book chapters were included in the study for review (Fig.1)

\section{ROLE OF ANTIBIOTICS}

It is reported that antibiotic resistance of bacteria present in biofilm is 1000-1500 times greater than the bacteria present as pure cultures. ${ }^{11}$ Moreover, use of antibiotics alone for the treatment of periodontal disease can be insufficient, therefore, for successful results, antibiotics should be given in combination with RSI., ${ }^{9,12}$ According to the $6^{\text {th }}$ consensus statement on periodontology, it can be suggested that systemic antibiotics should be administered on the visit in which mechanical debridement is completed. ${ }^{13,14}$ On the other hand, locally delivered antibiotics should be placed soon after RSI. ${ }^{10}$ There are several mechanisms by which the antibiotics affect the pathogens like inhibiting the cell wall synthesis, inhibiting ribosomal protein synthesis, suppressing DNA synthesis, inhibiting folic acid synthesis and altering the cell membrane permeability. ${ }^{15}$ Ideally, antibiotic sensitivity and culture testing of plaque samples should be carried out before selection of antibiotics. ${ }^{10,16}$ There are a variety of antibiotics which are used in management of periodontal diseases and they can be either systemically administered or locally delivered.

\section{SYSTEMIC VERSUS LOCAL ADMINISTRATION OF ANTIBIOTICS}

Most common route for systemic antibiotics is oral administration. However, in some cases intravenous or intramuscular injections of antibiotics can be given. On the other hand, locally delivered antibiotics can be placed in periodontal pockets by various drug delivery systems. These systems may include fibers, films, strips and polymers (biodegradable and non-biodegradable). ${ }^{17}$ According to Mombelli, ${ }^{18}$ systemic antibiotics are distributed throughout the body resulting in lower concentration in periodontal pockets but might be effective against bacteria that are present elsewhere in the oral cavity such as tongue and tonsils. Moreover, administration of systemic antibiotics can cause some side effects, resulting in poor patient compliance. ${ }^{18}$ On the other side, locally placed antibiotics achieve higher concentration but are only effective against bacteria confined to that specific site. Moreover, locally placed antibiotics require minimum patient compliance and have negligible adverse effects. ${ }^{18}$

\section{COMMONLY USED ANTIBIOTICS}

Tetracycline: Tetracycline acts against gram positive as well as gram negative bacteria. ${ }^{7,19}$ Derivatives of tetracycline are also present which are doxycycline and minocycline and these derivates are more lipophilic, thus they can be administered in low doses. ${ }^{7}$ Tetracycline is a bacteriostatic antibiotic when administered systematically and acts by inhibiting protein synthesis in bacterial cell. ${ }^{19}$ However, upon local administration of tetracycline in pockets, it acts as bactericidal. ${ }^{7}$

Systemic administration: Several studies and clinical trials have been carried out to show the efficiency of systemic administered tetracycline. Clinical studies on patients with localized aggressive periodontitis showed considerable resolution of tissue inflammation and increase in clinical attachment when treated with tetracycline in conjunction with $\mathrm{RSI}^{20,21}$ However, disease recurrence can take place in $25 \%$ of patients with localized aggressive periodontitis after receiving systemic tetracycline. ${ }^{21}$ Clinical Study performed by Hellden showed no significant difference in the outcome of chronic periodontitis when treated with tetracycline in combination with RSI and when compared with RSI only. ${ }^{22}$

Local delivery: The purpose of local delivery of antibiotics is to achieve greater concentration of drug in periodontal pockets compared with systemic delivery. ${ }^{7}$ Moreover, locally delivered antibiotics acts as bacteriocidal and can kill bacteria that are resistant to systemic antibiotics. ${ }^{7}$ Actisite containing $12.7 \mathrm{mg}$ tetracycline-HCL and Atridox containing $10 \%$ doxycycline hyclate have been used for localized delivery. Multiple studies have shown positive effect in probing depth and clinical attachment gain when treated with Actisite or Atridox in combination with RSI. ${ }^{23,24}$ Arestin is another drug consisting of $1 \mathrm{mg}$ minocycline and has also shown improvements in probing depth and attachment gain when used in conjunction with RSI. ${ }^{25}$

Penicillin/Augmentin: Penicillin is bactericidal against gram positive and gram negative bacteria and acts by inhibiting cell wall synthesis. ${ }^{7,26}$ However, penicillin can 
be ineffective against most bacteria in periodontal pockets as these bacteria produce $\beta$-Lactamase enzyme which destroy the $\beta$-Lactam ring of penicillin. ${ }^{7}$ To overcome the resistance of bacteria, Augmentin was introduced which consist of amoxicillin and clavulanic acid. Clavulanic acid is a $\beta$-lactamase inhibitor and causes $\beta$-lactamase enzyme to bind to it instead of amoxicillin and thus making amoxicillin available for antimicrobial activity. ${ }^{7}$ Clinical study by Magnusson on patients with refractory periodontitis showed $2 \mathrm{~mm}$ of attachment gains and decrease in probing depths when treated with RSI and Augmentin. ${ }^{27} \mathrm{How}-$ ever, use of Augmentin combined with mechanical plaque removal in chronic periodontitis did not demonstrate any additional positive results. ${ }^{28}$

Clindamycin: Clindamycin is bacteriostatic against gram positive and gram negative bacteria and acts by inhibiting protein synthesis. ${ }^{7}$ However, certain bacteria like Aggregatibacter actinomycetemcomitans ( $\mathrm{Aa}$ ) and Eikenella corrondens can be resistant to clindamycin therefore making it ineffective in cases of aggressive periodontitis. ${ }^{29,30}$ Study performed by Gordon in 1990 showed increased clinical attachments and decrease probing depths in patients with refractory periodontitis. Moreover, use of clindamycin may cause adverse effects including pseudomembranous colitis, thus clindamycin has a limited use in periodontal treatment. ${ }^{7}$

Metronidazole: Metronidazole is bactericidal against gram negative bacteria and acts by suppressing DNA synthesis of bacteria. ${ }^{7}$ However, some bacteria like Fusobacterium and Aa may develop resistance. ${ }^{31}$

Systemic: Multiple studies have shown positive effects of metronidazole when used as adjunct to RSI. Studies performed by Winkelhoff and Gusberi showed increase in clinical attachment, decrease in probing depth and decrease bleeding on probing in patients with aggressive or refractory periodontitis. ${ }^{32,33}$

Local: Metronidazole can be delivered locally in periodontal pockets in the form of a gel called Elyzol consisting of $25 \%$ metronidazole benzoate. Gel may be administered in 2 visits one week apart. Griffiths performed a study on patients with chronic periodontitis using locally delivered metronidazole with RSI. ${ }^{34}$ Study showed decrease in probing depths and increase attachment gains. However, another clinical study performed by Riep showed no significant difference over root surface instrumentation alone when patients with chronic periodontitis were treated with metronidazole gel in combination with RSI. ${ }^{35}$

Azithromycin: Azithromycin acts against gram positive as well as gram negative bacteria. ${ }^{7}$ Generally, dosage of $250 \mathrm{mg}$, once daily for 4 days may be given as this dosage can maintain concentration in periodontal tissues for up to 10 days. ${ }^{7}$ Smith reported a clinical study in

J Med Sci 2021 July;29(3):122-125 which $300 \mathrm{mg}$ of azithromycin daily for 3 days were given to patients with periodontal disease. Significant reduction in probing depths and reduced bleeding were charted after 22 weeks. ${ }^{36}$ Moreover, azithromycin was given as an adjunct to RSI. However, more studies are required to evaluate the true efficacy of azithromycin in treatment of periodontal diseases.

\section{ANTIBIOTICS IN SPECIFIC PERIODONTAL DIS- EASE}

Chronic Periodontitis: It is a condition causing gingival inflammation, attachment loss and bone loss and is characterized by pocket formation and gingival recession. ${ }^{3}$ Use of antibiotics in chronic periodontitis is not indicated as the pathogens in this condition can be poorly defined and may cause rapid recolonization following antibiotics. ${ }^{16}$ Moreover, chronic periodontitis responds well following $\mathrm{RSI}^{37}$

Aggressive Periodontitis: It can be either in localized or generalized form. Localized form can be characterized by bone and attachment loss around molars and/ or incisors with no more than two teeth involved other than first molar and incisors, while generalized form is characterized by rapid bone loss and attachment loss interproximally involving at least three teeth other than first molar and incisors. ${ }^{3}$ Traditionally, tetracycline $250 \mathrm{mg}, 4$ times daily for 2 weeks was prescribed in combination with $\mathrm{RSI} .{ }^{16}$ However, due to tetracycline resistance of Aa, current regimen is metronidazole 375 or $400 \mathrm{mg}$ plus amoxicillin 250mg, 3 times daily for 1 week in combination with RSI. ${ }^{16}$ This current regimen may result in $97 \%$ elimination of Aa. ${ }^{16,38}$ Result of a study performed by Guerrero in 2005 on patients with generalized aggressive periodontitis showed improvements in probing depths and clinical attachment gains when treated with RSI combined with amoxicillin $(500 \mathrm{mg})$ and metronidazole $(500 \mathrm{mg}), 3$ times daily for 7 days. ${ }^{39}$ On the other hand, different dentists have different regimen for antibiotics. ${ }^{40}$. (Table 2).

Acute Periodontal Abscess: It is characterized by collection of pus within the periodontal tissues. ${ }^{3}$ Use of antibiotics may not be suggested in cases where the pus can be drained via RSI or incision. ${ }^{16}$ However, when there is danger of systemic spreading of abscess or abscess is not drainable then amoxicillin $250 \mathrm{mg}$ or metronidazole 200mg, 3times daily for 5 days can be suggested. ${ }^{16}$ Herrera performed a clinical study on patients with acute periodontal abscess in which one group received azythromycin (500mg, once daily for 3days), while other group received augmentin $\left(500 \mathrm{mg}\right.$, 3times a day for 8 days). ${ }^{41}$ Both groups showed significant resolution in abscess and improvement in probing depth with decrease pathogen count. Necrotizing Ulcerative Gingivitis and Periodontitis(NUG): Can be characterized by punched out papilla with pain and bleeding followed by pseudomembrane formation, while Necrotizing ulcerative periodontitis (NUP) 
Systemic And Local Delivery Of Antibiotics In Managing Periodontal Diseases: An Update

can be presented as NUG with infection spreading to ligaments and alveolar bone resulting in bone exposure. ${ }^{3}$ After $\mathrm{RSI}$, metronidazole 200mg, 3 times a day for 3 days can be prescribed. ${ }^{16}$ Resistance of microorganisms against antibiotics: Approximately $7-11 \%$ of commonly used antibiotics are prescribed by dentists and improper use of antibiotics can lead to their resistance. ${ }^{42}$ Moreover, resistant bacteria may pass from one individual to another via contact and other modes of transmission. ${ }^{43}$ Bacteria and other pathogens are smart and they can acquire resistance against antibiotics. ${ }^{42}$ Mechanism by which the bacteria can evade the effects of antibiotics are inactivation of enzymes, alteration of the receptor sites, limiting access to target sites, efflux of the drug from cells, preventing activation of drug or excessive production of target sites. ${ }^{15,44}$

Table 1: Modified and taken from Wiebe. ${ }^{45}$ Adapted from 1999 International workshop for classification of periodontal diseases and conditions. ${ }^{46}$

\begin{tabular}{|c|}
\hline $\begin{array}{l}\text { Simplified Classification of periodontal diseases and } \\
\text { conditions }\end{array}$ \\
\hline I. Gingival Diseases \\
\hline A. Dental plaque-induced gingival diseases \\
\hline B. Non-plaque-induced gingival lesions \\
\hline $\begin{array}{l}\text { II. Chronic Periodontitis (Slight: 1-2 mm CAL; moderate: } \\
\text { 3-4 mm CAL; severe: > } 5 \mathrm{~mm} \mathrm{CAL)}\end{array}$ \\
\hline A. Localized \\
\hline B. Generalized ( $>30 \%$ of sites are involved) \\
\hline $\begin{array}{l}\text { III. Aggressive Periodontitis (Slight: 1-2 mm CAL; moder- } \\
\text { ate: 3-4 mm CAL; Severe: > } 5 \mathrm{~mm} \mathrm{CAL)}\end{array}$ \\
\hline A. Localized \\
\hline B. Generalized ( $>30 \%$ of sites are involved) \\
\hline IV. Periodontitis as a Manifestation of Systemic Diseases \\
\hline A. Associated with hematological disorders \\
\hline B. Associated with genetic disorders \\
\hline C. Not otherwise specified \\
\hline V. Necrotizing Periodontal Diseases \\
\hline A. Necrotizing ulcerative gingivitis \\
\hline B. Necrotizing ulcerative periodontitis \\
\hline VI. Abscesses of the Periodontium \\
\hline A. Gingival abscess \\
\hline B. Periodontal abscess \\
\hline C. Pericoronal abscess \\
\hline VII. Periodontitis Associated With Endodontic Lesions \\
\hline A. Combined periodontic-endodontic lesions \\
\hline $\begin{array}{l}\text { VIII. Developmental or Acquired Deformities and Condi- } \\
\text { tions }\end{array}$ \\
\hline $\begin{array}{l}\text { A. Localized tooth-related factors that modify or predispose to } \\
\text { plaque-induced gingival diseases }\end{array}$ \\
\hline B. Mucogingival deformities and conditions around teeth \\
\hline $\begin{array}{l}\text { C. Mucogingival deformities and conditions on edentulous } \\
\text { ridges }\end{array}$ \\
\hline D. Occlusal trauma \\
\hline
\end{tabular}

Table 2: Antibiotics regimen in periodontal diseases suggested by Walker ${ }^{10}$ in 2002

\begin{tabular}{|c|c|c|c|}
\hline No. & $\begin{array}{c}\text { Antibiotic } \\
\text { Name }\end{array}$ & Adult Dosage & Duration \\
\hline 1 & $\begin{array}{c}\text { Amoxicillin/ } \\
\text { Augmentin }\end{array}$ & $\begin{array}{c}250 \mathrm{mg} \text { or } 500 \mathrm{mg} \\
3 \text { times daily }\end{array}$ & 10 days \\
\hline 2 & $\begin{array}{c}\text { Amoxicillin } \\
+\end{array}$ & $\begin{array}{c}375 \mathrm{mg} \text { or } 400 \mathrm{mg} \\
\text { amoxillicin } \\
3 \text { times daily } \\
+\end{array}$ & 7 days \\
Metronidazole & $\begin{array}{c}250 \mathrm{mg} \text { Metronidazole } \\
3 \text { times daily }\end{array}$ & \\
\hline 3 & Clindamycin & $\begin{array}{c}300-150 \mathrm{mg} \\
4 \text { times daily }\end{array}$ & $\begin{array}{c}14-10 \\
\text { days }\end{array}$ \\
\hline 4 & Metronidazole & $\begin{array}{c}250 \mathrm{mg} \\
3 \text { or } 4 \text { times daily }\end{array}$ & 10 days \\
\hline 5 & Tetracycline & $\begin{array}{c}250 \mathrm{mg} \\
4 \text { times daily }\end{array}$ & $\begin{array}{c}21-14 \\
\text { days }\end{array}$ \\
\hline
\end{tabular}

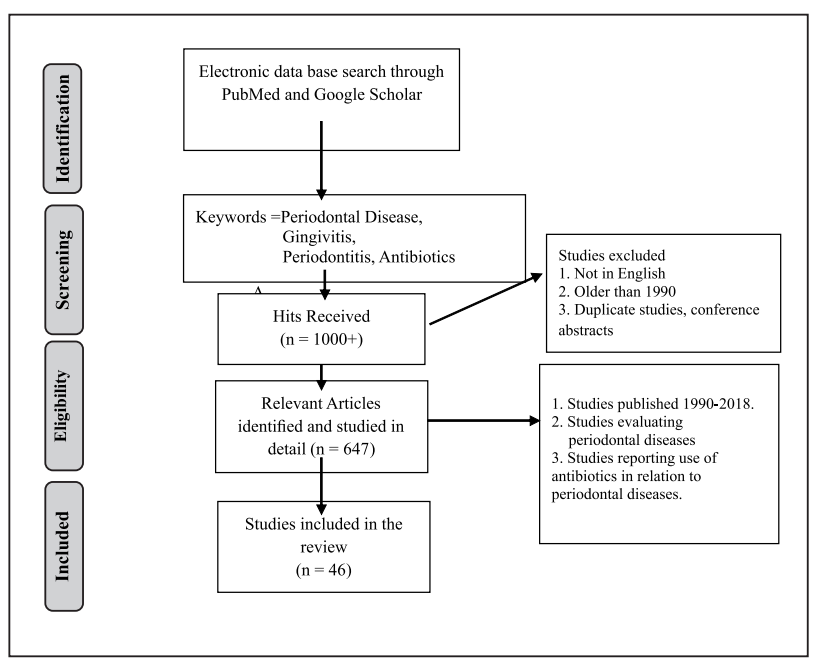

Fig 1: Flowchart showing identification, screening, and selection of studies for this review.

\section{CONCLUSION}

The main aim of periodontal therapy should be to eliminate or control the undesired effects of bacteria present in oral cavity in the form of biofilms. Therefore, mechanical instrumentation is required to physically disrupt the biofilms. Nevertheless, the bacteria have the tendency to re-colonize following mechanical therapy, therefore use of antibiotics can play a major role in the treatment of periodontal diseases. Use of antibiotics can be justified in cases with rapid signs and symptoms of destruction of periodontal tissues. Hence, antibiotics can be suggested in cases of aggressive periodontitis, periodontal abscess, necrotizing ulcerative gingivitis, necrotizing ulcerative periodontitis and periodontitis that do not respond well to RSI. However, antibiotics may cause side effects and the bacteria may develop resistance, therefore dentists should keep in mind the adverse effects and benefits while prescribing antibiotics. Moreover, antibiotics should always be given as an adjunct to RSI and oral hygiene 
instructions to achieve successful outcome.

\section{REFERENCES}

1. Meisel P, Kocher T. Photodynamic therapy for periodontal diseases: state of the art. J Photochemistry and Photobiology B, Biology. 2005 May 13;79(2):159-70.

2. Albandar JM. Epidemiology and risk factors of periodontal diseases. Dental Clinics of North America. 2005 Jul;49(3):517-32, v-vi.

3. American Academy of Periodontolgy. Glossary of Periodontol Terms, 4th ed. Chicago: 2001;44.

4. Ryan ME. Nonsurgical approaches for the treatment of periodontal diseases. Dental Clinics of North America. 2005 Jul;49(3):611-36, vii.

5. Slots J. Subgingival microflora and periodontal disease. J Clinical Periodontology. 1979 Oct;6(5):351-82.

6. Slots J, Ting M. Systemic antibiotics in the treatment of periodontal disease. Periodontology 2000. 2002;28:10676.

7. Walker CB, Karpinia K, Baehni P. Chemotherapeutics: antibiotics and other antimicrobials. Periodontology 2000. 2004;36:146-65.

8. Heitz-Mayfield LJ. Systemic antibiotics in periodontal therapy. Australian Dental J. 2009 Sep;54 Suppl 1:S96101.

9. Haffajee AD, Dibart S, Kent RL, Jr., Socransky SS. Clinical and microbiological changes associated with the use of 4 adjunctive systemically administered agents in the treatment of periodontal infections. J Clinical Periodontology. 1995 Aug;22(8):618-27

10. Walker C, Karpinia K. Rationale for Use of Antibiotics in Periodontics. J Periodontology. 2002;73(10):1188-96.

11. Costerton JW. Introduction to biofilm. Inter J Antimicrobial Agents. 1999 May;11(3-4):217-21; discussion 37-9.

12. Eisenberg L, Suchow R, Coles RS, Deasy MJ. The effects of metronidazole administration on clinical and microbiologic parameters of periodontal disease. Clinical Preventive Dentistry. 1991 Jan;13(1):28-34.

13. Herrera D, Alonso B, Leon R, Roldan S, Sanz M. Antimicrobial therapy in periodontitis: the use of systemic antimicrobials against the subgingival biofilm. J Clinical Periodontology. 2008 Sep;35(8 Suppl):45-66.

14. Sanz M, Teughels W. Innovations in non-surgical periodontal therapy: Consensus Report of the Sixth European Workshop on Periodontology. J Clinical Periodontology. 2008 Sep;35(8 Suppl):3-7.

15. Pallasch TJ. Antibiotic resistance. Dental Clinics of North America. 2003 Oct;47(4):623-39.

16. Preshaw PM. Antibiotics in the treatment of periodontitis. Dental Update. 2004 Oct;31(8):448-50, 53-4, 56.

17. Schwach-Abdellaoui K, Vivien-Castioni N, Gurny R. Local delivery of antimicrobial agents for the treatment of periodontal diseases. European J Pharmaceutics and Biopharmaceutics. $2000 \mathrm{Jul} ; 50(1): 83-99$.

18. Mombelli A. Antibiotics in Periodontal Therapy. In: Lindhe J, Lang P, editors. Clinical periodontology and implant dentistry. 5th ed. Oxford: Blackwell Munksgaard;2008. Vol. 2. p.882-897.

19. Chopra I, Roberts M. Tetracycline antibiotics: mode of action, applications, molecular biology, and epidemiology of bacterial resistance. Microbiology and Molecular Biology Reviews. 2001 Jun;65(2):232-60 ; second page, table of contents.

20. Novak MJ, Polson AM, Adair SM. Tetracycline therapy in patients with early juvenile periodontitis. J Periodontology. 1988 Jun;59(6):366-72.

21. Lindhe J, Liljenberg B, Adielsson B. Effect of long-term tetracycline therapy on human periodontal disease. $\mathrm{J}$ Clinical Periodontology. 1983 Nov;10(6):590-601.

22. Hellden LB, Listgarten MA, Lindhe J. The effect of tetracycline and/or scaling on human periodontal disease. $\mathrm{J}$ Clinical Periodontology. 1979 Aug;6(4):222-30.

23. Drisko CL, Cobb CM, Killoy WJ, Michalowicz BS, Pihlstrom BL, Lowenguth RA, et al. Evaluation of periodontal treatments using controlled-release tetracycline fibers: clinical response. J Periodontology. 1995 Aug;66(8):6929.

24. Garrett S, Adams DF, Bogle G, Donly K, Drisko $\mathrm{CH}$, Hallmon WW, et al. The effect of locally delivered controlled-release doxycycline or scaling and root planing on periodontal maintenance patients over 9 months. J Periodontology. 2000 Jan;71(1):22-30.

25. Williams RC, Paquette DW, Offenbacher S, Adams DF Armitage GC, Bray K, et al. Treatment of periodontitis by local administration of minocycline microspheres: a controlled trial. J Periodontology. 2001 Nov;72(11):1535-44.

26. Yocum RR, Rasmussen JR, Strominger JL. The mechanism of action of penicillin. Penicillin acylates the active site of Bacillus stearothermophilus D-alanine carboxypeptidase. J Biological Chemistry. 1980 May 10;255(9):3977-86.

27. Magnusson I, Clark WB, Low SB, Maruniak J, Marks RG, Walker CB. Effect of non-surgical periodontal therapy combined with adjunctive antibiotics in subjects with "refractory" periodontal disease. (I). Clinical results. J Clinical Periodontology. 1989 Nov;16(10):647-53.

28. Winkel EG, van Winkelhoff AJ, Barendregt DS, van der Weijden GA, Timmerman MF, van der Velden U. Clinical and microbiological effects of initial periodontal therapy in conjunction with amoxicillin and clavulanic acid in patients with adult periodontitis. A randomised double-blind, placebo-controlled study. J Clinical Periodontology. 1999 Jul;26(7):461-8.

29. Loesche WJ, Schmidt E, Smith BA, Morrison EC, Caffesse R, Hujoel PP. Effects of metronidazole on periodontal treatment needs. Journal of Periodontology. 1991 Apr;62(4):247-57.

30. Walker CB. The acquisition of antibiotic resistance in the periodontal microflora. Periodontology 2000. 1996 Feb;10:79-88.

31. Muller HP, Holderrieth S, Burkhardt U, Hoffler U. In vitro antimicrobial susceptibility of oral strains of Actinobacillus actinomycetemcomitans to seven antibiotics. J Clinical Periodontology. 2002 Aug;29(8):736-42.

32. Gusberti FA, Syed SA, Lang NP. Combined antibiotic 
(metronidazole) and mechanical treatment effects on the subgingival bacterial flora of sites with recurrent periodontal disease. J Clinical Periodontology. 1988 Jul;15(6):353-9.

33. van Winkelhoff AJ, Vangsted T, Winkel EG. [Metronidazole in the treatment of refractory periodontitis]. Nederlands Tijdschrift voor Tandheelkunde. 2000 Aug;107(8):327-31.

34. Griffiths GS, Smart GJ, Bulman JS, Weiss G, Shrowder J, Newman HN. Comparison of clinical outcomes following treatment of chronic adult periodontitis with subgingival scaling or subgingival scaling plus metronidazole gel. J Clinical Periodontology. 2000 Dec;27(12):910-7.

35. Riep B, Purucker P, Bernimoulin JP. Repeated local metronidazole-therapy as adjunct to scaling and root planing in maintenance patients. J Clinical Periodontology. 1999 Nov;26(11):710-5.

36. Smith SR, Foyle DM, Daniels J, Joyston-Bechal S, Smales FC, Sefton A, et al. A double-blind placebo-controlled trial of azithromycin as an adjunct to non-surgical treatment of periodontitis in adults: clinical results. J Clinical Periodontology. 2002 Jan;29(1):54-61.

37. Van der Weijden GA, Timmerman MF. A systematic review on the clinical efficacy of subgingival debridement in the treatment of chronic periodontitis. J Clinical Periodontology. 2002;29 Suppl 3:55-71; discussion 90-1.

38. Van Winkelhoff AJ, Rodenburg JP, Goene RJ, Abbas F, Winkel EG, de Graaff J. Metronidazole plus amoxycillin in the treatment of Actinobacillus actinomycetemcomitans associated periodontitis. J Clinical Periodontology. 1989 Feb;16(2):128-31.

39. Guerrero A, Griffiths GS, Nibali L, Suvan J, Moles DR, Laurell L, et al. Adjunctive benefits of systemic amoxicillin and metronidazole in non-surgical treatment of generalized aggressive periodontitis: a randomized placebo-controlled clinical trial. J Clinical Periodontology. 2005 Oct;32(10):1096-107.

40. Saxen L, Asikainen S. Metronidazole in the treatment of localized juvenile periodontitis. J Clinical Periodontology. 1993 Mar;20(3):166-71.

41. Herrera D, Roldan S, O'Connor A, Sanz M. The periodontal abscess (II). Short-term clinical and microbiological efficacy of 2 systemic antibiotic regimes. J Clinical Periodontology. 2000 Jun;27(6):395-404.
42. Pallasch TJ. Global antibiotic resistance and its impact on the dental community. Jthe New Jersey Dental Assoc. 2000 Spring;71(2):14-5, 8-9, 22-3 passim.

43. Wormser GP, Bergman MM. The Antibiotic Paradox: How the Misuse of Antibiotics Destroys Their Curative Powers, 2nd Edition By Stuart B. Levy Cambridge, Massachusetts: Perseus Publishing, 2002. 376 pp., illustrated. $\$ 17.50$ (paper). Clinical Infectious Dis. 2003 January 15, 2003;36(2):238.

44. Kaye KS, Kaye D. Multidrug-resistant Pathogens: Mechanisms of Resistance and Epidemiology. Current Infectious DisReports. 2000 Oct;2(5):391-8.

45. Wiebe CB, Putnins EE. The periodontal disease classification system of the American Academy of Periodontology--an update. J Canadian Dent Assoc. 2000 Dec;66(11):594-7.

46. 1999 International International Workshop for a Classification of Periodontal Diseases and Conditions. Papers. Oak Brook, Illinois, October 30-November 2, 1999. Annals of Periodontology. 1999 Dec;4(1):i, 1-112.

CONFLICT OF INTEREST: Authors declare no conflict of interest

GRANT SUPPORT AND FINANCIAL DISCLOSURE: NIL

\section{AUTHOR'S CONTRIBUTION}

Following authors have made substantial contributions to the manuscript as under

Khabeer A: Concept, Design and Proof reading

Alam BF: Acquisition and critical review

Noreen S: Analysis and interpretation of data

Faridi MA: Data collection, Final approval

Ali S: logical interpretation and presentation of the results

Authors agree to be accountable for all aspects of the work in ensuring that questions related to the accuracy or integrity of any part of the work are appropriately investigated and resolved. 